\title{
THERMAL PERFORMANCE EVALUATION OF SINGLE SLOPE SOLAR STILL WITH PCM AS THERMAL STORAGE MATERIALS
}

\author{
*Sameh, S. Kishk
}

\section{ABSTRACT}

The main objective of the present study was to improve the productivity of a single-slope solar still using phase change materials (PCM) as a heat energy storage material. Three identical single slope solar stills were constructed and functioned with and without PCM at the Agricultural Engineering Department, Faculty of Agriculture, Suez Canal University, Egypt (latitude angle of $30.62^{\circ} \mathrm{N}$ and Longitude angle of $32.27^{\circ} \mathrm{E}$ ). Paraffin wax was used to store the solar thermal energy in the form of latent heat, which can offer high storage capacity per unit volume, and also due to its feasible general and economic properties. The basin of solar still was rectangular, with a net upper surface area of $1.04 \mathrm{~m}^{2}$. It is painted with matt black paint to absorb the maximum possible amount of solar radiation incident on it. The solar still was covered with glass sheet $3 \mathrm{~mm}$ thick and inclined with a tilt angle of $31^{\circ}$ of the horizontal plane. The three solar stills (solar still without PCM, solar still with $5 \mathrm{~kg}$ PCM and solar still with $10 \mathrm{~kg}$ PCM) were examined. The obtained results clarified that, the highest productivity of fresh water $\left(207 \mathrm{ml} / \mathrm{m}^{2} \mathrm{~h}\right)$ was achieved from the solar still with $10 \mathrm{~kg}$ PCM followed by the still with 5 $\mathrm{kg}$ PCM (182 $\left.\mathrm{ml} / \mathrm{m}^{2} \mathrm{~h}\right)$ and the still without PCM $\left(151 \mathrm{ml} / \mathrm{m}^{2} \mathrm{~h}\right)$. The thermal efficiency of the three solar stills with 5 and $10 \mathrm{~kg}$ PCM, and without PCM, respectively, was 34.9\%, 39.6\% and 28.9\%. The obtained data also revealed that, the $\mathrm{pH}$ (7.46), EC (0.21 $\mu \mathrm{s} / \mathrm{cm})$, and TDS (134.4 ppm) values were lower than those of the brackish water (7.8, 48.5 $\mu \mathrm{s} / \mathrm{cm}$ and 31040 ppm, respectively).

\section{INTRODUCTION}

7 he amount of solar energy reaching the earth surface is nearly thousand times greater than the availability of fossil fuels. Solar radiation can be the source of heat energy where brackish or sea water is evaporated and is then condensed as pure water (El-Sebaii et al., 2009).

*Lecturer of Agric. Eng. Dep., Fac. of Agric., Suez Canal Univ., 41522 Ismailia, Egypt. 
Solar distillation is one of many processes that can be used for water purification. Solar still is a device that produces clean water from dirty water using the energy from the sun. This inexpensive device can easily be built using local materials (Kantesh, 2012). There is a strong need to improve the solar still performance and increase the production of water distillation (Sundaram et al., 2016). The thermal energy storage system has been widely used to increase energetic efficiency of different applications (Ramasamy and Sivaraman, 2013). The thermal storage material can be classified into the latent and the sensible heat thermal storage material (Kabeel and Abdelgaied, 2016). The latent heat thermal storage material has a significant advantage over sensible heat thermal storage material, including a large amount of energy storage per unit mass. Paraffin waxes used in solar still applications, due to its availability and low cost (Sharma et al., 2009). Heat is absorbed when the material changes its phase from solid to liquid and vice versa. Here PCM is used to store heat in the day time and release the heat during night which gives continuous production of distilled water. Single slope stills considered as one of the cheapest solutions for purifying see water and suitable for the Middle East and Africa (Goosen et al., 2000). Singh and Tiwari (2004) found that the productivity of the solar still was maximized when the condensing glass cover inclination is equal to the latitude of the place. Murugavel et al., (2008) found that production of the solar still with 3 $\mathrm{mm}$ thick glass cover more than production that covered with $6 \mathrm{~mm}$ thick glass cover. Solar still with (PCM) had constructed by Naim and Abd El Kawi (2002). They found that the use of storage material led to a larger productivity of fresh water. Al-Hamadani and Shukla (2011) found that the higher mass of (PCM) with lower mass of water in solar still basin significantly increased the daily productivity and efficiency. Dashtban and Tabrizi (2011) developed a theoretical model for solar still with and without (PCM). They concluded that the daily productivity of the solar still with and without the PCM was 6.7 and $5.1 \mathrm{~kg} / \mathrm{m}^{2}$ day, respectively. Solar still with PCM was studied by Kantesh (2012). He found that the efficiency for solar still with PCM was higher than still without PCM. Arunkumar et al. (2013) studied the effect of thermal storage material on the solar still productivity. They found that, the productivity of the still 
with PCM was $26 \%$ higher than the still without PCM. Performance of solar still with PCM was also studied by Al-Hamadani and Shukla (2014). The productivity of solar still with PCM was found increasing during post sunset operation which occurred. Solar still integrated with Paraffin wax as PCM was studied by Sathyamurthy et al. (2014). They found an increase of about 35\% in production of fresh water with PCM higher than that of solar still without PCM. Solar still integrated with PCM thermal storage was evaluated by Sundaram et al. (2016). The performance test is conducted with and without phase change material (PCM). The increased efficiency of desalinated water by using the paraffin wax as thermal energy storage material is $9.9 \%$. The aim of study is to evaluate the effect of paraffin wax as a phase change material on the productivity of solar stills, under climatic conditions of Egypt at Ismailia city during the period of the $24^{\text {th }}$ September till the $3^{\text {th }}$ October 2017.

\section{MATERIALS AND METHODS}

\section{Experimental setup}

Three similar single sloped solar stills were constructed and tested at the Agricultural Engineering Department, Faculty of Agriculture, Suez Canal University (Ismailia Governorate), Egypt (latitude angle of $30.62{ }^{\circ} \mathrm{N}$ and Longitude angle of $32.27^{\circ} \mathrm{E}$ ). The basin of solar still is rectangular in shape made of galvanized iron sheet having gross dimensions $1.30 \mathrm{~m}$ long, $0.80 \mathrm{~m}$ wide and $0.10 \mathrm{~m}$ deep with net surface area of 1.04 . It is painted by red-lead primer thereafter by matt-type black paint in order to maximize the absorbed solar radiation. The solar still is covered with 3 mm thick of clear glass, and inclined by $31^{\circ}$ of horizontal plane to transmit the maximum possible of solar radiation flux incident on it as revealed in Figs (1) and (2). Otherwise, with this inclined angle $\left(31^{\circ}\right)$ condensation will run down the underneath of glass cover into the trough rather than dropping from the cover into the basin. Glass cover has been sealed with silicone rubber which plays an important role to promote efficient operation of condensation as it can accommodate the expansion and contraction between dissimilar materials. The supported frame for each still is made of iron posts. To minimize heat loss from the bottom, 
sides, and perimeter of the galvanized basins, each basin was fitted by an external wooden box of an identical shape with a slightly larger size. The gaps between each wooden and galvanized sheet were packed with 70 $\mathrm{mm}$ thick of styrofoam (thermal conductivity $=0.04 \mathrm{~W} \mathrm{~m}^{-1} \mathrm{~K}^{-1}$ ). Paraffin wax is selected as the PCM due to its safety, good reliability, congruent melting and moderate cost.

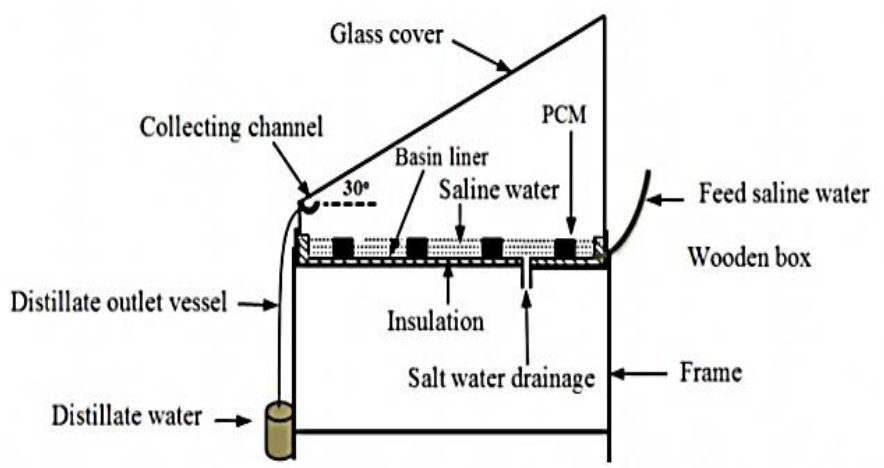

Fig. (1): Schematic diagram of experimental setup of solar still with PCM
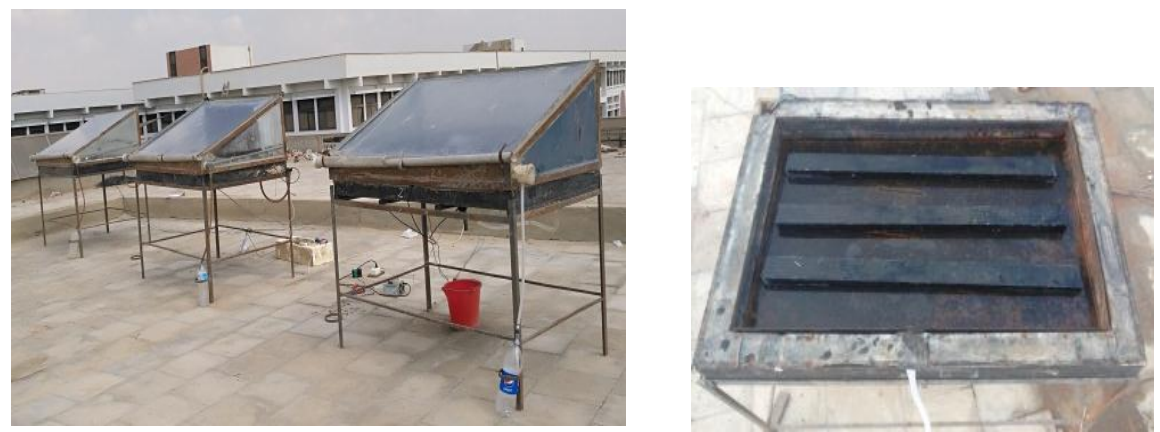

Fig. (2): Three single slope solar stills with and without PCM

A phase change material tubes are installed with the solar still and filled by PCM. The walls of the PCM tubes are made of aluminum. The PCM tubes are rectangular in shape having gross dimensions of $120 \mathrm{~cm}$ long, 8 $\mathrm{cm}$ wide and $4 \mathrm{~cm}$ deep. A horizontal tube loaded with the PCM through a pipe has sufficient space for the volumetric expansion of the melting PCM. Paraffin wax with a mass of 5 and $10 \mathrm{~kg}$ were used because of its wide availability and its low cost. The thermo-physical properties of paraffin wax are summarized and listed in Table (1) (Sathyamurthy et al., 2014). To collect the distilled water from the solar still a trough is placed along the three bottom sides (northern, southern and eastern sides) 
of the glass cover. The distilled water is continuously collected in a plastic vessel located outside the still and measured using a graduated cylinder. An inlet pipe is also fixed at the rear wall of the still for feeding brackish water.

Table (1): Thermo-physical properties of paraffin wax

\begin{tabular}{|l|l|}
\hline Properties & Value \\
\hline Solid / liquid density $\left(\mathrm{kg} \mathrm{m}^{-3}\right)$ & $818 / 760$ \\
\hline Melting temperature $\left({ }^{\circ} \mathrm{C}\right)$ & $40-60$ \\
\hline Latent heat of fusion $\left(\mathrm{kJ} \mathrm{kg}^{-1}\right)$ & 226 \\
\hline Thermal conductivity $\left(\mathrm{W} \mathrm{m}^{-1}{ }^{\circ} \mathrm{C}^{-1}\right)$ & 0.25 \\
\hline Specific heat of solid liquid $\left(\mathrm{kJ} \mathrm{kg}^{-1}{ }^{\circ} \mathrm{C}^{-1}\right)$ & $2.95 / 2.51$ \\
\hline
\end{tabular}

\section{Measurements and data acquisition}

Meteorological station (Vantage Pro 2, Davis, USA) located above the roof of the Agricultural Engineering Department was used to measure different macroclimate variables such as incident solar radiation (pyranometer), ambient air temperatures and wind speed. Eight thermocouples with a range of 0 to $100^{\circ} \mathrm{C}$ with an accuracy of $\pm 0.1^{\circ} \mathrm{C}$ were functioned to measure the temperatures of various points of each solar still system (basin water temperature, $\mathrm{T}_{\mathrm{w}}$, vapour temperature, $\mathrm{T}_{\mathrm{v}}$, inside glass temperature, $\mathrm{T}_{\mathrm{g}}$, paraffin wax temperatures inside the aluminum tube, $\mathrm{T}_{\mathrm{p}}$ ). These sensors were connected to a data-logger system (Lab-Jack logger, USA) to display and record the data during the experimental period. The output data were recorded every ten minutes and averaged every one hour using the data logging program.

\section{Methods}

During operating the solar stills, solar radiation was transmitted through the glass cover and absorbed by both the brackish water and the black metallic surface of basin bottom. Part of the absorbed energy by the basin bottom is transferred by convection to the brackish water. Another part of the heat energy was used to melt the paraffin wax. As the tubes are heated the heat is transferred to PCM and charging process is started to store solar energy as a sensible heat till PCM reaches its melting temperature. Additional charging heat is stored as the latent heat during the melting process. When the absorber surface temperature is lower than that the PCM (prior to sunset), reverse process is occurred (discharging process) 
till the PCM layer is completely solidified. Condensate water was flowed by gravity into the collection trough at the lower edges of the tilted glass cover (glass cover was at sufficient slope $31^{\circ}$ ). Therefore, surface tension of the water was induced to flow the condensed water into the trough without dropping back into the basin. Plastic container was used for collecting the distilled water coming out from the solar still. Suez Canal water was used as feed. Experimental work was carried out on successive days during August month of 2017. The experiments were continued until $8 \mathrm{~h}$ of the next day. The yield from the still was collected and measured every $1 \mathrm{~h}$ during the day time and night period. The three stills were positioned on a suitable steel structure and facing south direction. The first solar still was used without PCM as a control unit. The second still was functioned with the $5 \mathrm{~kg}$ PCM. The third still was operated with the $10 \mathrm{~kg}$ PCM. The concentration of hydrogen ion $(\mathrm{pH})$, electrical conductivity (EC, $\mu \mathrm{s} / \mathrm{cm}$ ), and total dissolved solids (TDS, ppm) of the brackish water, respectively, were 7.8, $48.5 \mu \mathrm{s} / \mathrm{cm}$ and $31040 \mathrm{ppm}$.

\section{Overall thermal efficiency of the solar still}

The daily average overall thermal efficiency $\left(\eta_{d}\right)$ for the solar still was computed based on the daily average condensate production ( $\mathrm{M}$ in $\mathrm{kg}$ ), latent heat $(\mathrm{L}$ in $\mathrm{kJ} / \mathrm{kg})$ at an average basin water temperature $\left(\mathrm{T}_{\mathrm{w}}\right)$, daily average incident solar radiation $\left(\mathrm{I}\right.$ in $\mathrm{W} / \mathrm{m}^{2}$ ), surface area of the solar still $\left(\mathrm{A}\right.$ in $\mathrm{m}^{2}$ ).The overall thermal efficiency of solar still is calculated using the following formula Kantesh (2012):

$$
\eta_{\mathrm{d}}=\frac{\mathrm{M} \mathrm{L}}{3.6 \mathrm{I} \mathrm{A}} \times 100 \%
$$

The average latent heat (L) was determined by Kabeel and Abdelgaied, (2016) as follows:

$$
\begin{gathered}
\mathrm{L}=10^{-3}\left(2501.9-2.40706 \mathrm{~T}_{\mathrm{w}}+1.192217 \times 10^{-3} \mathrm{~T}_{\mathrm{w}}{ }^{2}-1.5863 \times 10^{-5} \mathrm{~T}_{\mathrm{w}}{ }^{3}\right) \\
\text { 3. RESULTS AND DISCUSSION }
\end{gathered}
$$

For the duration of the experimental work, the three similar solar stills were operated satisfactorily without malfunction. The hourly average incident solar radiation on the saline water inside the solar still, temperatures and distillate productivity were simultaneously measured and recorded. The hourly average incident solar radiation and the hourly 
average ambient air temperature is plotted in Fig. (3). The hourly average intensity of solar radiation gradually increased from sunrise until reaching the maximum value at noon, and then it gradually decreased until reaching the minimum value prior to sunset. During the experimental tests, the hourly average incident solar radiation was $396.1 \mathrm{~W} \mathrm{~m}^{-2}$, whilst, the hourly average air temperature outside the solar stills was $26.9^{\circ} \mathrm{C}$.

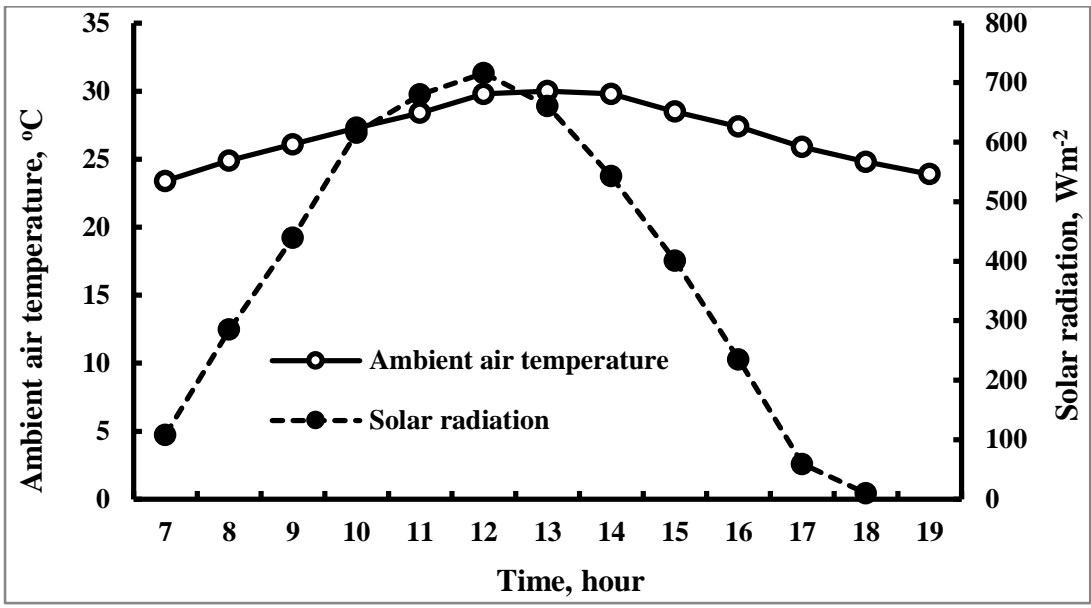

Fig. (3): Hourly average incident solar radiation and ambient air

\section{temperature versus solar time on the $24^{\text {th }}$ September 2017}

Fig (4) specifies the variations in saline water temperatures for the three solar stills during the day. It observed that, the saline water temperatures were reached to the maximum values at and around the solar noon and lowered during the morning and late afternoon hours. This occurred according to the intensity of incident solar radiation. As a result higher evaporation rate of the basin water was achieved. It also observed that, the maximum saline water temperatures for the solar stills without PCM, with $5 \mathrm{~kg}$ PCM, and with $10 \mathrm{~kg}$ PCM, which achieved at solar noon, respectively, were $60.1,60.5$ and $59.8^{\circ} \mathrm{C}$ due to the maximum amount of absorbed solar radiation at that time. Afternoon, saline water temperatures for the three solar stills were decreased because the heat energy losses from the solar stills to the convective surrounding environment increased, particularly when the water temperatures were higher than the absorbed solar radiation rate. The hourly average saline water temperatures for the three solar stills were $44.3,46.2$ and $47.6^{\circ} \mathrm{C}$, respectively. The highest 
hourly average saline water temperature during the daylight-time was achieved from the solar still with $10 \mathrm{~kg}$ PCM. The saline water temperature can be considered as one of the most important parameters that substantially affecting the productivity of fresh water.

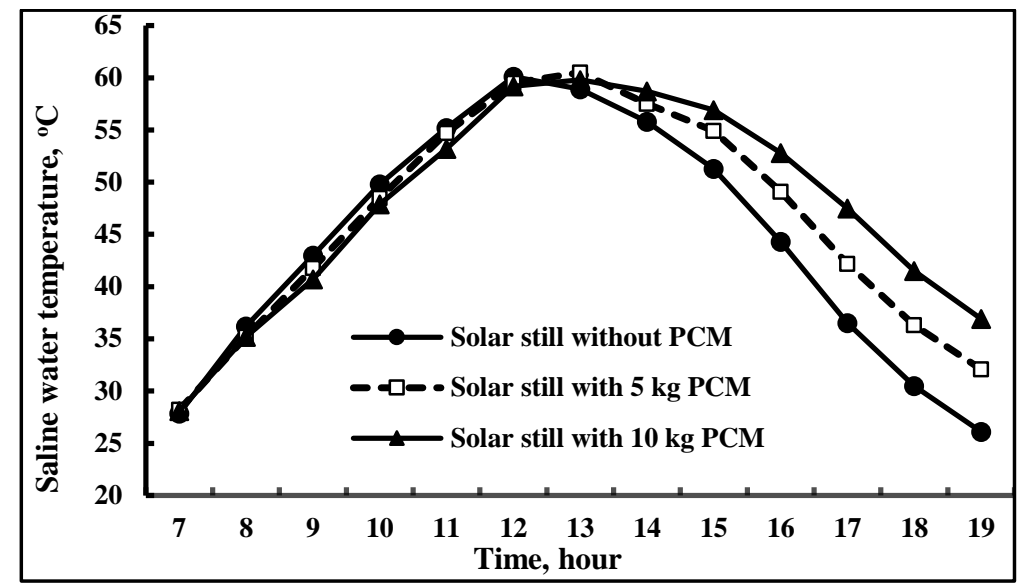

Fig. (4): Hourly average saline water temperatures for the three solar stills

The water vapour temperatures were found to be the highest operating temperatures for the three different solar stills due to the particles of vapour have enough heat energy (comprises sensible and latent heat) to evaporate. The distributions of the hourly average water vapour temperatures for the three solar stills were plotted in Fig. (5). It clearly revealed that, the water vapour temperatures were reached to their peak values at $13 \mathrm{~h}$. It is noticed that, the hourly average water vapour temperatures for the three solar stills, respectively, were 47.4, 49.3 and $50.8^{\circ} \mathrm{C}$.

The hourly average inner glass temperatures for the three solar stills are plotted in Fig. (6). As the glass cover temperature is lower than the dew point temperature of water vapour, much more condensation of water vapour on the inner surface of glass cover occurred. In the early morning (from $7-8 \mathrm{~h}$ ), the glass temperature was closest to the water vapour temperatures resulting in lower productivity due to the lower heat energy absorbed by the water at these times. The hourly average inner glass temperatures for the three solar stills (without PCM, with $5 \mathrm{~kg} \mathrm{PCM}$, and with $10 \mathrm{~kg}$ PCM), respectively, were $40.7,44.4$ and $42.2^{\circ} \mathrm{C}$. 


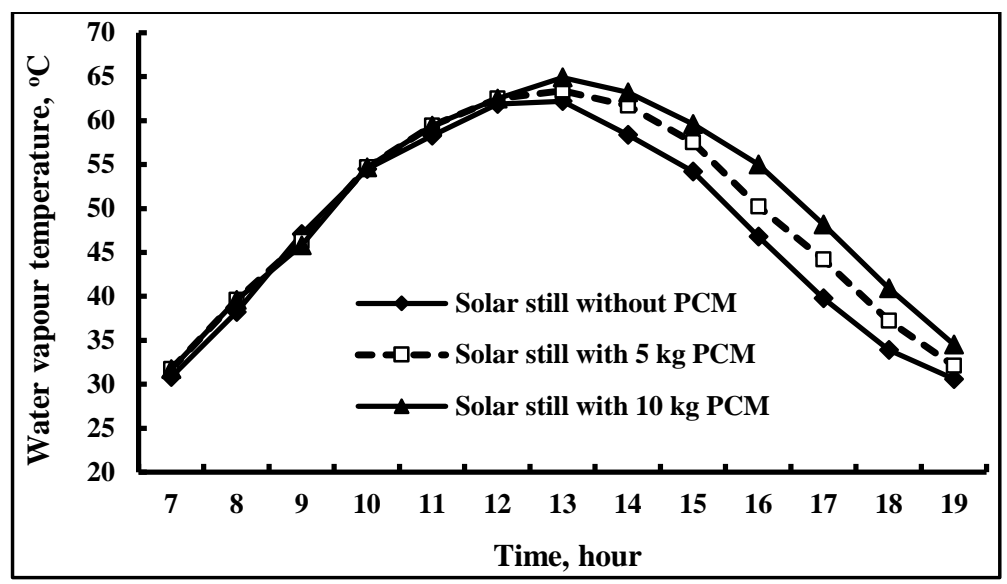

Fig. (5): Water vapour temperature for the three solar stills versus solar time

The temperature difference between the water and glass acts as a driving force of desalination process. Higher the temperature difference increases the productivity and evaporation rate. Fig (7) depicts the temperature difference between water and glass cover. It clearly revealed that, in the early morning the glass cover temperature is slightly higher than the water temperature because at that period glass is directly faces the solar radiation and its temperature rises faster as compared with the water temperature, as a result the difference has a negative values. These differences remained negative till water temperature exceeded the glass cover temperature. The maximum positive differences for the three solar stills were $7.6,9.0$ and $9.7^{\circ} \mathrm{C}$, respectively.

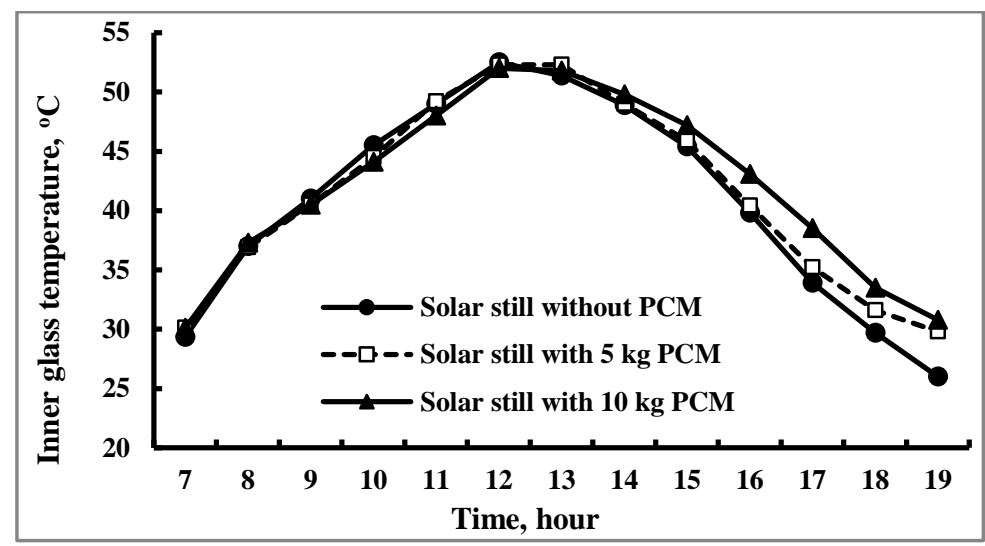

Fig. (6): Hourly average temperatures of inner glass cover for the three solar stills with and without PCM 
The hourly average paraffin wax temperatures are plotted in Fig. (8). The paraffin wax starts to melt in the early morning due to the high intensity of incident solar radiation. It evidently showed that, the increase in temperature is directly proportional to the input energy which is similar to the trends of solar radiation. The hourly average paraffin wax temperatures for the two solar stills were 45.1 and $46.5^{\circ} \mathrm{C}$, respectively. The PCM temperatures which measured and recorded were approximately closed to the basin water temperature at $15 \mathrm{~h}$ after reaching the melting point of $\mathrm{PCM}\left(54^{\circ} \mathrm{C}\right)$. Thereafter, the paraffin wax was under the charging mode of heat transfer. As a result, the PCM increase the basin water temperature and consequently the productivity throughout the day. Subsequently, with a decrease in temperature, it becomes solid again releasing sensible heat into water, even after the sunset. The latent energy stored in the paraffin wax kept the system to be operated during the nighttime and delivered distillate water output.

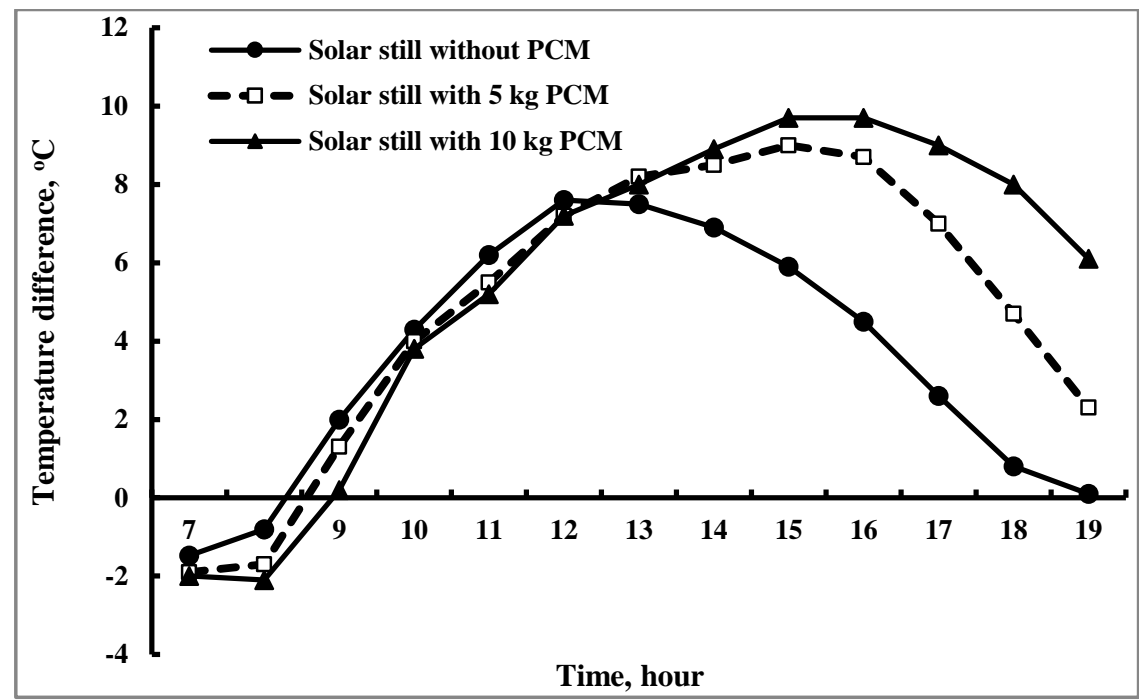

Fig. (7): Hourly average temperature difference between saline water and inner glass cover for the three solar stills

The economical productivity rate of fresh water reflects how much the solar stills were adapted to the heat storage material. The productivity rate of fresh water in $\mathrm{ml} / \mathrm{m}^{2} \mathrm{~h}$ for the three solar stills is shown in Fig. (9). 


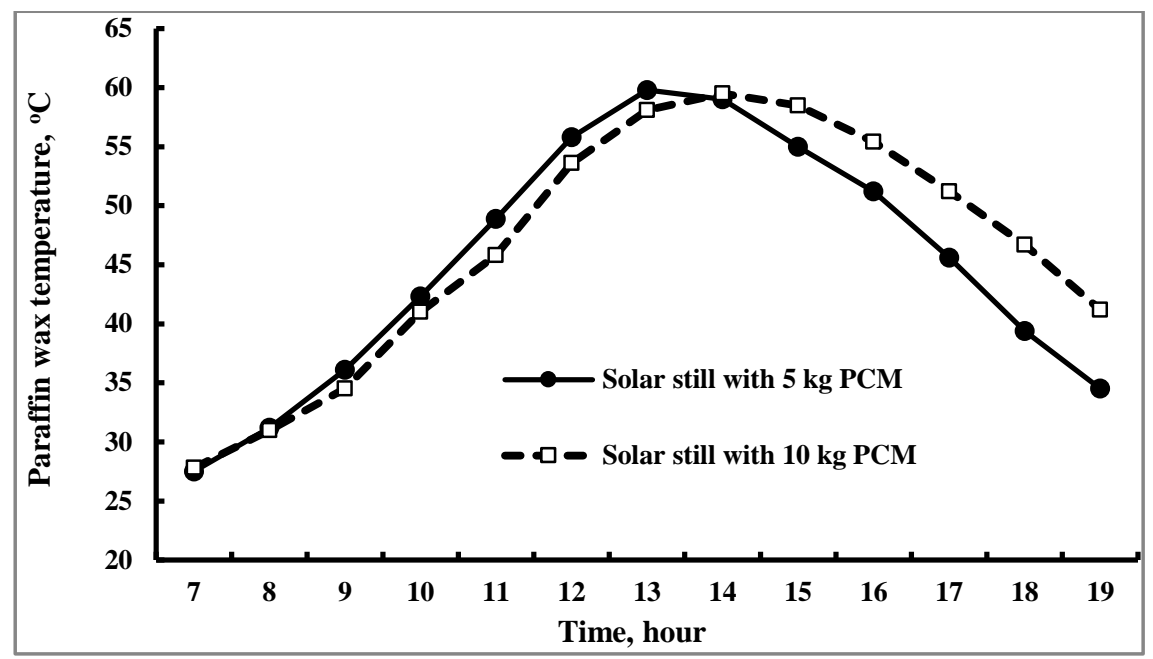

Fig. (8): Hourly average temperatures of paraffin wax

Results showed that, the solar intensity is directly proportional to the yield of fresh water from the solar still due to the increase in heat energy gained by the saline water at which vaporization inside the stills increased (Sathyamurthy et al., 2014). It can be seen that, the productivity of fresh water for the three solar stills gradually increased from early morning until reached the maximum values afternoon. Daily average productions of fresh water from the three solar stills (without PCM, with $5 \mathrm{~kg}$ PCM and $10 \mathrm{~kg} \mathrm{PCM}$ ), respectively, were 151,182 and $207 \mathrm{ml} / \mathrm{m}^{2} \mathrm{~h}$.

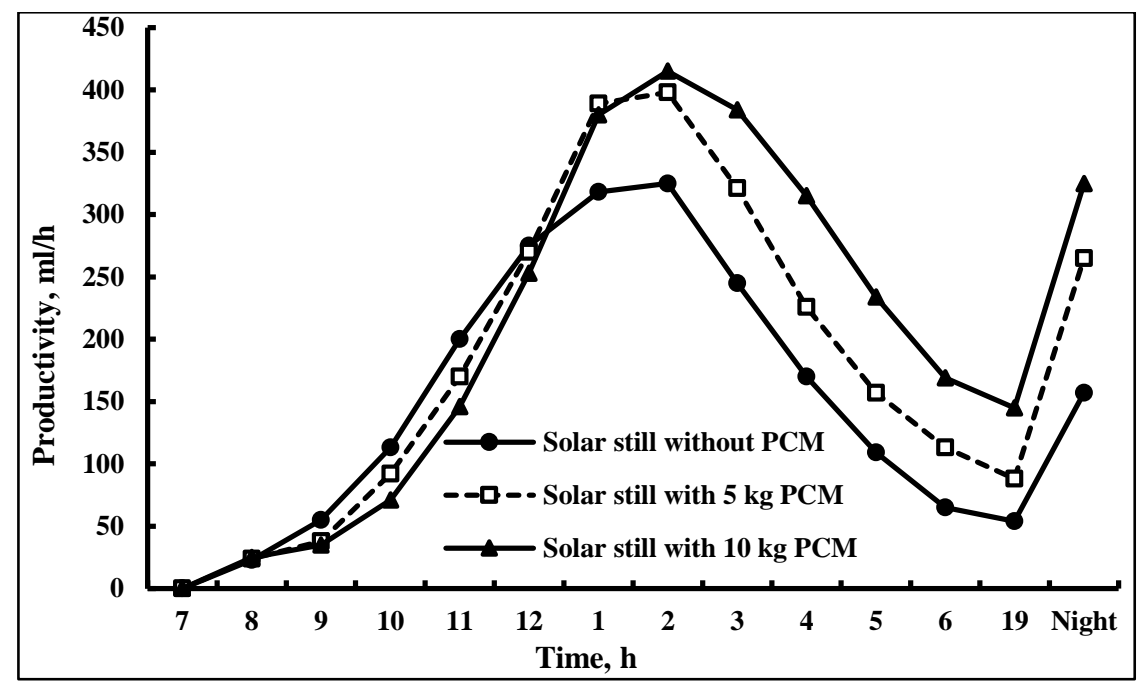

Fig. (9): Hourly average productivity rates for the three solar stills 
The accumulated fresh water yield for the solar stills with and without heat storage material is plotted in Fig. (10). The daily average productivity of fresh water from the three solar stills approximately reached to 2109,2551 , and $2897 \mathrm{ml} / \mathrm{m}^{2}$ day, respectively. The experimental results showed that, the daily average productivity of fresh water for the two solar stills with PCM was higher than that of the conventional solar still. The highest productivity rate was achieved from the solar still with $10 \mathrm{~kg}$ PCM due to the higher specific heat capacity, better latent heat of fusion, and thermal conductivity of paraffin wax. Therefore, the productivity rate of fresh water at nighttime and during the daylight-time for the two solar stills with PCM increased by 21.0 and $37.4 \%$ as compared with the conventional solar still, respectively. As a result, using PCM in solar still was found to be the best option to increase the solar still productivity not only during the daylight-time but also at the nighttime. These data are in agreement with that published by Kabeel and Abdelgaied (2016).

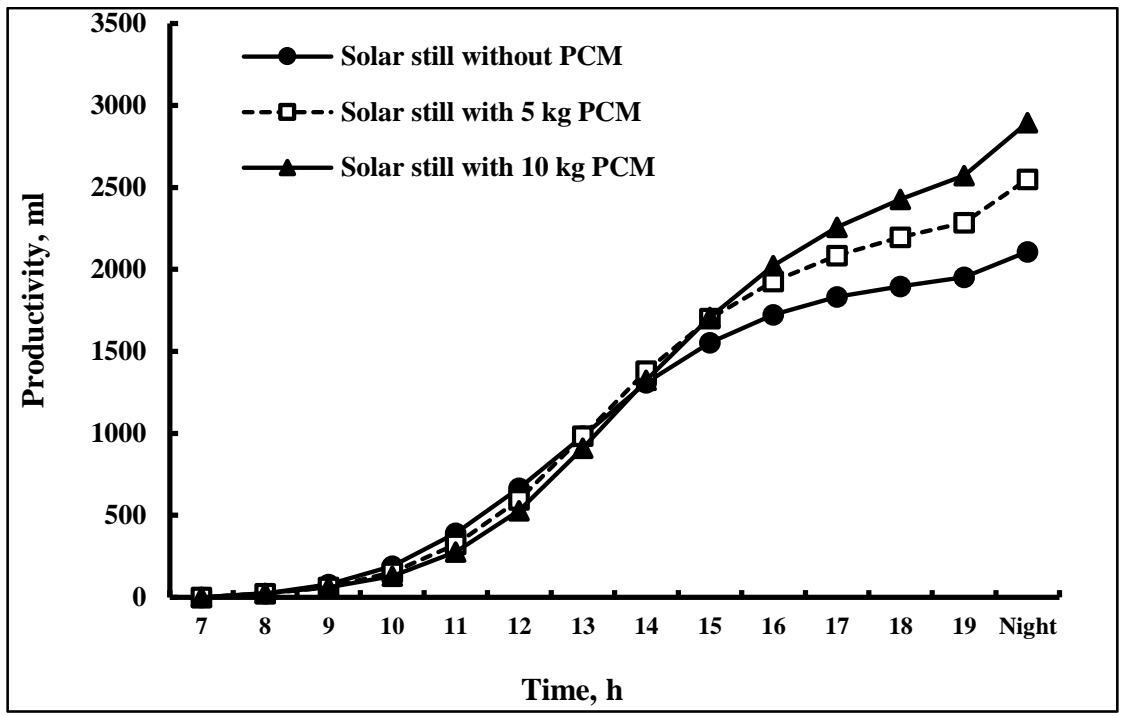

Fig. (10): Effect of PCM on the accumulated productivity of solar stills

The thermal efficiency of the solar still is considered the most important factor could be used to evaluate the thermal performance. The hourly average thermal efficiencies for the three solar stills were $28.9 \%, 34.9 \%$, 
and $39.6 \%$, respectively. The addition amount of the storing materials was definitely improving the thermal performance of the single slope solar still by increasing the overall water collection over $24 \mathrm{~h}$. Therefore, the hourly average thermal efficiency for the two solar stills with 5 and $10 \mathrm{~kg}$ PCM increased by 20.8 and $37 \%$, as compared with the conventional solar still, respectively.

\section{Quality of distilled water}

The $\mathrm{pH}, \mathrm{EC}$ and TDS values of the brackish water and the solar distilled water which obtained from the experimental work are summarized and listed in Table (2). These values were found to be much lower (7.46, 0.21 $\mu \mathrm{s} / \mathrm{cm}$ and $134.4 \mathrm{ppm}$, respectively) than those of the brackish water (7.8, $48.5 \mu \mathrm{s} / \mathrm{cm}$ and $31040 \mathrm{ppm}$, respectively). The quality of potable water distilled from solar still is suitable for drinking particularly in remote areas.

Table (2): Quality parameters (pH, EC, and TDS) of the solar distilled water and brackish water during the experimental tests

\begin{tabular}{lcc}
\hline \multicolumn{1}{c}{ Parameter } & $\begin{array}{c}\text { Brackish } \\
\text { water }\end{array}$ & $\begin{array}{l}\text { Distilled } \\
\text { water }\end{array}$ \\
\hline $\mathrm{pH}$ & 7.8 & 7.46 \\
Electrical conductivity (EC), $\mu \mathrm{s} / \mathrm{cm}$ & 48.5 & 0.21 \\
Total Dissolved Solids (TDS), $\mathrm{ppm}$ & 31040 & 134.4 \\
\hline
\end{tabular}

\section{CONCLUSION}

In this present research work, several conclusions can be obtained and drawn as follows:

1- Hourly average temperatures of saline water for the three solar stills (without PCM, with $5 \mathrm{~kg}$ PCM and with $10 \mathrm{~kg}$ PCM) were 44.3, 46.2 and $47.6^{\circ} \mathrm{C}$, respectively.

2- Hourly average water vapour temperatures for the three solar stills, (without PCM, with $5 \mathrm{~kg}$ PCM and with $10 \mathrm{~kg}$ PCM) respectively, were $47.4,49.3$ and $50.8^{\circ} \mathrm{C}$.

3- The productivity rate of distillated water at nighttime and during the daylight-time for the two solar stills with $5 \mathrm{~kg}$ and $10 \mathrm{~kg}$ PCM 
increased by 15.9 and $29.5 \%$ as compared with the conventional solar still, respectively.

4- The hourly average thermal efficiency for the three solar stills was $28.9 \%, 34.9 \%$, and $39.6 \%$, respectively.

5- The $\mathrm{pH}$ (7.46), EC (0.21 $\mu \mathrm{s} / \mathrm{cm})$, and TDS (134.4 ppm) values were lower than those of the brackish water $(7.8,48.5 \mu \mathrm{s} / \mathrm{cm}$ and 31040 ppm, respectively).

6- Using PCM in solar still was found to be the best option to increase the solar still productivity not only during the daylight-time but also at the nighttime.

\section{REFERENCES}

Al-Hamadani, A. A. F.; and Shukla, S. K. (2011) "Water distillation using solar energy system with Lauric acid as storage medium" International Journal of Energy Engineering, 1(1): 1-8.

Al-Hamadani, A. A. F.; and Shukla, S. K. (2014) "Modelling of solar distillation system with phase change material storage medium" Thermal science, 18 (2): 347-362.

Arunkumar, T.; Denkenberger, D.; Ahsan, A.; and Jayaprakash, R. (2013) "The augmentation of distillate yield by using concentrator coupled solar still with phase change material" Desalination, 314, 189-192

Dashtban, M.; and Tabrizi, F. F. (2011) "Thermal analysis of a weirtype cascade solar still integrated with PCM storage" Desalination, $279,415-422$.

El-Sebaii, A. A.; Al-Ghamdi, A. A.; Al-Hazmi, F. S.; and Faidah, A. S. (2009) "Thermal performance of a single basin solar still with PCM as a storage medium" Applied Energy, 86, 1187-1195

Goosen, M. F. A.; Sablani, S. S.; Shayya, W. H.; Paton, C.; and AlHinai, H. (2000) "Thermodynamic and economic considerations in solar desalination" Desalination, 129: 63-89 
Kabeel, A. E.; and Abdelgaied, M. (2016) "Improving the performance of solar still by using PCM as a thermal storage medium under Egyptian conditions" Desalination, 383: 22-28.

Kantesh, D. C (2012) "Design of solar still using Phase changing material as a storage medium" International Journal of Scientific \& Engineering Research, 3, 12.

Murugavel, K. K.; Chockalingam, K. S. K.; and Srithar, K. (2008) "Progresses in improving the effectiveness of the single basin passive solar still" Desalination, 220: 677-686.

Naim, M. M;. and Abd El Kawi, M. A. (2002) "Non-conventional solar stills part 2, Non-conventional solar stills with energy storage element" Desalination 153, 71-80

Ramasamy, S.; and Sivaraman, B. (2013) "Heat transfer enhancement of solar still using phase change materials (PCMs)" International Journal of Engineering and Advanced Technology, 2, 3

Sathyamurthy, R.; Nagarajan, P. K.; Kennady, H. J.; Ravikumar, T. S.; Paulson, V.; And Ahsan, A. (2014) "Enhancement of fresh water production on triangular pyramid solar still using phase change material as storage material" Frontiers in Heat And Mass Transfer, 5, 3 .

Sharma, A.; Tyagai, V. V, Chen,; C. R.; and Buddhi, D. (2009)" Review on thermal energy storage with phase change materials and applications" Renewable and Sustainable Energy Reviews, 13, 318 -345 .

Singh, H. N.; and Tiwari, G. N. (2004) "Monthly performance of passive and active solar stills for different Indian climatic conditions" Desalination, 168, 145 - 150

Sundaram, P.; Mohan, D. S.; and Kumar, M. P. (2016) "Evaluation of pyramidal slope solar still integrated with PCM thermal storage" International Journal of Chem. Tech. Research, 9 (9): 230 - 236. 


\section{الملخص العربي}

تآثير المواد متعددة الأطوار على الأداء الحرارى للمقطرات الثمسية

\section{سامح سعيد كثك}

أجري هذا البحث بقسم الهندسة الزر اعية ـ كلية الزر اعة ـ جامعة قناة السويس ويهدف إلي تقييم

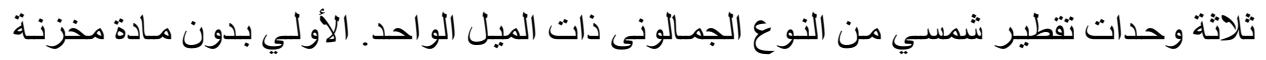

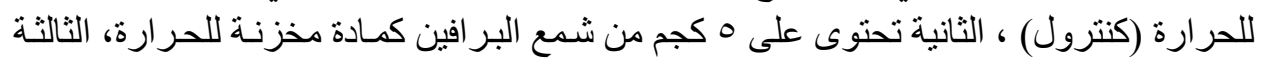

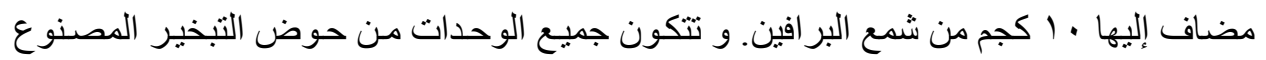

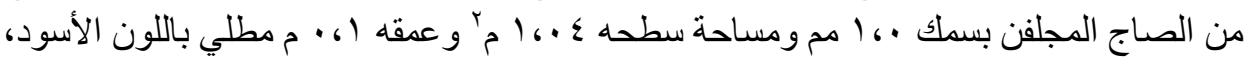

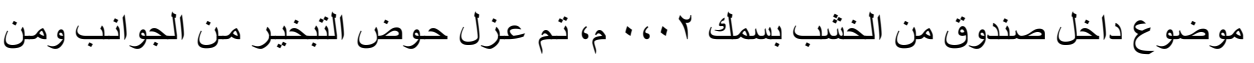

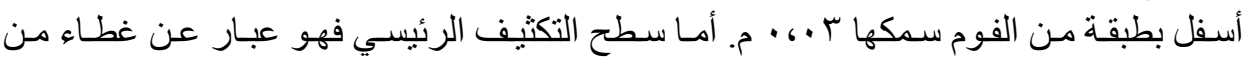

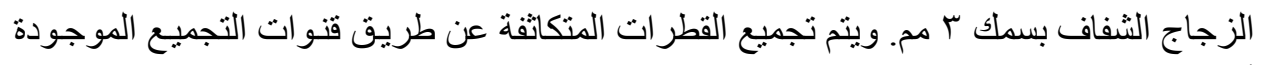

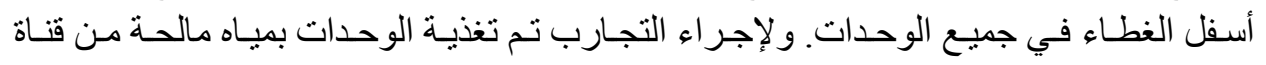

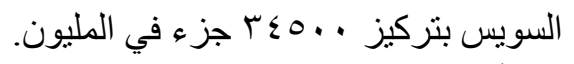
وقد أوضحت النتائج مايلي: مأه

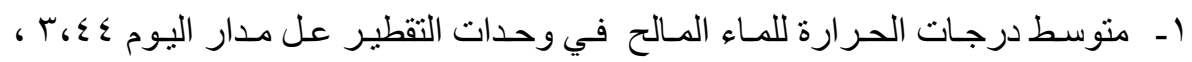

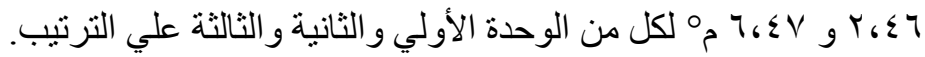

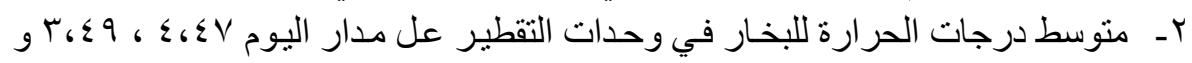

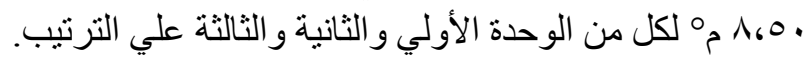

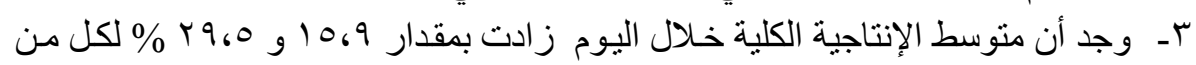

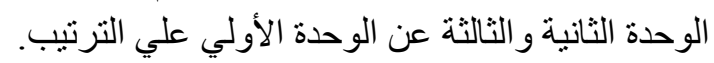

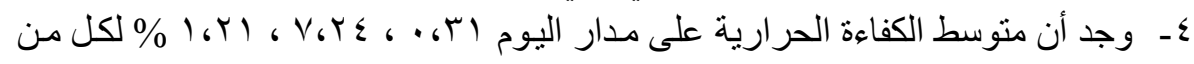

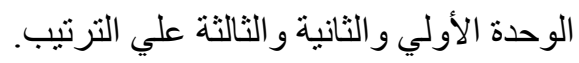

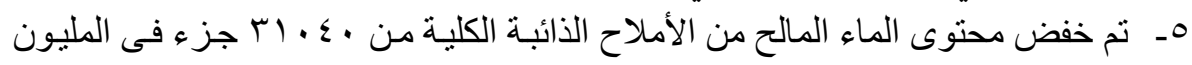
إلى ع، ع ا جزء في المليون للماء المقطر 